\title{
Method for Determining the Tribological Properties of the Cutting Fluid
}

Andrey Dugin, Jaroslav Votocek, Alexey Popov

Department of Machining and Assembly, Faculty of Mechanical Engineering, Technical University of Liberec.

461 17, Studentská 1402/2, Liberec 1, Czech Republic. E-mail: andrey.dugin@seznam.cz, jan.jersak@tul.cz, alespopov@yandex.com.

Application of cutting fluids is one of the most widely accepted methods of increasing not only the efficiency of machining but also the quality management of the working surface that is used in industry. The cutting fluid market is large enough, and different manufacturers produce their own cutting fluids in several product lines which differ as to their chemical composition and their properties. When creating a cutting fluid, the manufacturer is particularly interested in the study of its individual properties as well as studying the effect of various chemical components on the final properties of the cutting fluid. Different methods are used to study various properties of cutting fluids. This article presents the method for the study of the tribological properties of cutting fluids. This method has been applied while comparing 5 different cutting fluids.

Keywords: Machining, Cuttingfluid, Orthogonalcutting

\section{Acknowledgments}

This paper is related to the investigation on the Specific University Research Projects, which are supported by the Ministry of Education (MSMT) of the Czech Republic.

This paper is supported and financed by state budget of Czech Republic - Technological Agency of Czech Republic (project TA02021332).

\section{References}

[1] VENGUDUSAMY, B., GRAFL, A., NOVOTNY-FARKAS, F., SCHÖFMANN, W., (2013), Comparison of frictional properties of gear oils in boundary and mixed lubricated rolling-sliding and pure sliding contacts, Tribology International, 62, pp. 100-109

[2] ADHVARYU, A., ERHAN, S. Z., PEREZ J.M., (2004), Tribological studies of thermally and chemically modified vegetable oils for use as environmentally friendly lubricants, Wear, 257(3-4), pp. 359-367

[3] DENG, J., SONG, W., ZHANG, H., YAN, P., LIU, A., (2011), Friction and wear behaviors of the carbide tools embedded with solid lubricants in sliding wear tests and in dry cutting processes, Wear, 270(9-10), pp. $666-674$

[4] PERSSON, K., GÅHLIN, R., (2003), Tribological performance of a DLC coating in combination with water-based lubricants, Tribology International, 36(11), pp. 851-855

[5] NOVAK, M., DOLEZAL, R., (2012), G-Ratio in hardened steel grinding with different coolants, Manufacturing Technology, 12(13), pp. $192-197$.

[6] DE CHIFFRE, L., BELlUCO, W., (2000), Comparison of Methods for Cutting Fluid Performance Testing, CIRP Annals, 49(1):57-60

[7] POPOV, A., DUGIN, A., (2013), Study of reasons of increased active force using coolant with uncut chip thickness, The International Journal of Advanced Manufacturing Technology, October, pp.1-8.

[8] KHAN, M., M., A., MITHU, M., A., H., DHAR, (2009), Effects of minimum quantity lubrication on turning AISI 9310 alloy steel using vegetable oil-based cutting fluid, Journal of Materials Processing Technology, 209(15-16), pp. 5573-5583

[9] POPOV, A., DUGIN, A., (2013), A comparison of experimental estimation methods of the ploughing force in orthogonal cutting, International Journal of Machine Tools and Manufacture, 65, pp.37-40

[10]DUGIN, A., POPOV, A., (2013), Increasing the accuracy of the effect of processing materials and cutting tool wear on the ploughing force values, Manufacturing Technology, 13(2), pp. $169-173$.

[11] POPOV A, DUGIN A, (2013), Influence of Lubricant and Coolant Fluid on the Cutting Force in Small-Increment Planing, Russian Engineering Research, 33(2), pp. 84-85

[12] MRKVICA, I., NESLUŠAN, M., KONDERLA, R., JURKO, J., PANDA, A., (2012), Cutting forces by turning of Inconel 718 with inserts from different materials, Manufacturing Technology, 12(13), pp. $499-504$ 
[13]JÓZWIK, J., KURIC, I., SÁGA, M., LONKWIC, P., (2014), Diagnostics of CNC machine tools in manufacturing process with laser interferometer technology, Manufacturing Technology, 14(1), pp.23 - 30

[14]NAVES, V.T.G., DA SILVA, M.B., DA SILVA, F.J., (2013), Evaluation of the effect of application of cutting fluid at high pressure on tool wear during turning operation of AISI 316 austenitic stainless steel, Wear, 302(1-2), pp. 1201-1208

[15]DUGIN, A., POPOV, A., (2012), Effect of the processing materials on the ploughing force values, Manufacturing Technology, 12(13), pp. 169-173

[16]POPOV, A., DUGIN, A., (2012), Experimental Methods of Determining the Cutting Forces at the Tool's Rear Surface, Russian Engineering Research, 32(1), pp. 68-69

\section{Paper number: M201428}

Copyright $@$ 2014. Published by Manufacturing Technology. All rights reserved. 